\title{
HISTORY OF MEDICINE
}

\section{The medical career of Robert Seymour Bridges, FRCP (1844-1930): physician and Poet Laureate}

\section{G C Cook}

Postgrad Med J 2002;78:549-554

Robert Bridges $O M$ is the only medical graduate (he was elected to the Fellowship of the Royal College of Physicians of London in 1900) to have held the office of Poet Laureate. Educated at Corpus Christi College, Oxford and St Bartholomew's Hospital he practised as a casualty physician at his teaching hospital (where he made a series of highly critical remarks of the Victorian medical establishment) and subsequently as a full physician to the Great (later Royal) Northern Hospital. He was also a physician to the Hospital for Sick Children. It had for long been his intention to retire from the medical profession at the early age of 40 ! In 1913, Bridges was appointed Poet Laureate by King George $\mathrm{V}$, and following a disappointingly sparse output of "official" work, published his greatest literary contribution - The Testament of Beauty - on his 85th birthday.

Correspondence to: Dr G C Cook, Wellcome Library for the History and Understanding of Medicine, 183 Euston Road, London NW1 2BE UK; g.cook@ucl.ac.uk

Submitted 29 April 2002 Accepted 19 June 2002
$\mathrm{R}$ obert Bridges (1844-1930) (fig 1) is the sole medical graduate (to date) to have attained the Poet Laureateship-the first holder of that office was John Dryden (1631-1700) who was appointed by King Charles II (1630-85) in 1668; Bridges was the 14th, ${ }^{1}$ and the present holder of the title (Andrew Motion; 1952- ) the 19th. Bridges was described by one obituarist as "one of the most remarkable figures of his time". ${ }^{2}$ It was his wish that no biography of him should be written, "and [this] will be respected by all who enjoyed his friendship"; so said a close personal friend-writing a biography in $1944^{3}$ that is, 14 years after his death.

\section{BIOGRAPHICAL NOTES}

Robert Seymour Bridges was born at Walmer, Kent ("in a house with grounds overlooking the Channel" $^{\prime 2}$ ) on 23 October $1844^{2-9}$; he was the fourth son and eighth child in a family of nine. His antecedents had been "Kentish yeomen" ( settled at Harbledown ${ }^{2}$ ) since the early 16th century. One ancestor was the Reverend John Bridges (or Brydges), who died in 1590, ${ }^{6}$ and was rector of Harbledown for 10 years from 1579. His father was John Thomas Bridges, of St Nicholas Court, Isle of Thanet, and his mother Harriet Elizabeth, the third daughter of the Reverend Sir Robert Affleck, Bt (who had succeeded to the baronetcy from his cousin in 1833), vicar of Silkstone, Yorkshire. ${ }^{8}$ Bridges lived his childhood years in his father's house Roselands, Walmer'; when in his 10th year, however, his father died (at the age of 47 years), and one year later, his mother married the Reverend Dr John Edward Nassau Molesworth ${ }^{2}$; she then moved to Rochdale, Lancashire (where her husband was vicar). In September 1854, still only 9 years old, Robert was sent to Eton, where he was (according to one biographer) extremely happy ${ }^{3}$; in his final year he was in the Oppidans' wall and field elevens. He proved to be a good cricketer (chiefly as an aggressive batsman, although he did occasionally bowl) and oarsman. ${ }^{3}$ While there, he enjoyed the "river, trees, and meadows, St George's chapel [Windsor] and the companionship of eager, high-souled youth". ${ }^{6}$ He also formed a close friendship with a boy four years his junior, Digby Mackworth Dolben (who accidentally drowned in $1867^{5}$ ) who had entered Eton in January 1862; Bridges shared with him a common great grandmother. With Dolben and several other friends, he formed "an ardent little High-Church set" ${ }^{2}$; with them he held "Puseyite views". ${ }^{6}$

In October 1863, Bridges went up to Corpus Christi College, Oxford"; he graduated BA with a second class degree in "Greats". While there he met Gerard Manley Hopkins (1844-89). In 1867, he stroked the Corpus boat, which "held the second place on the river" ${ }^{\prime 2}$; at the Paris Regatta, however, they lost by half a length to the Old Etonians! In 1874, he toured Egypt, Syria and Germany, ${ }^{2}$ and later visited France, Holland and Italy. ${ }^{2}$ In London, Bridges lived first at 50 Maddox

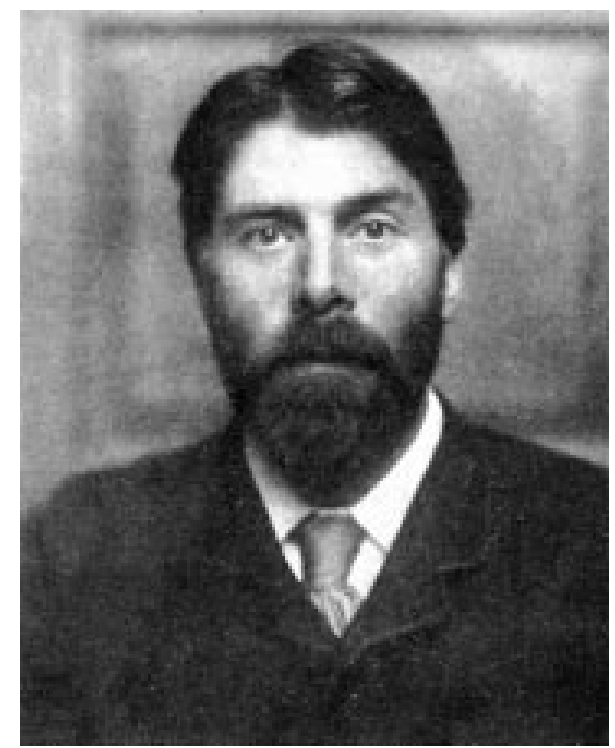

Figure 1 Robert Bridges (1844-1930): photograph as a young man (date unknown). ${ }^{17}$ 


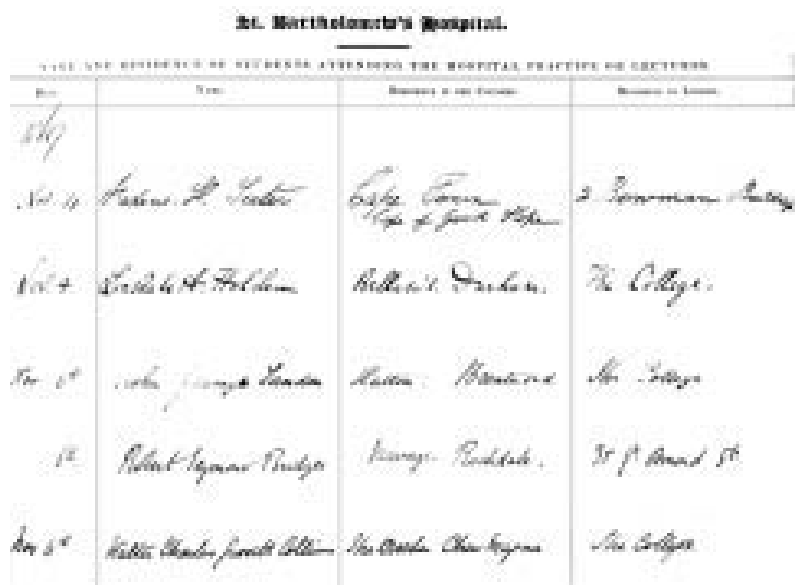

Figure 2 Entry in the St Bartholomew's Hospital Student Register on 6 November 1869. The entry is presumably written in Bridges' own hand. His lodgings were at 35 Great Ormond Street: "a few blocks from the British Museum and a short walk to the west of [St Bartholomew's] Hospital". ${ }^{9}$ In 1871-72 he moved to 50 Maddox Street, Hanover Square and shared a house with Harry Ellis Wooldridge. (Reproduced with permission-museum and archives, St Bartholomew's Hospital.)

Street (with his lifelong friend Harry Ellis Wooldridge; 18451917), and after his stepfather Molesworth's death (in 1877) with his mother at 52 Bedford Square. ${ }^{6}$

After distancing himself (in 1882) from medical professional life due principally to ill health (see below), he lived at the Manor House, Yattendon, Berkshire (initially with his mother). ${ }^{6}$ With Wooldridge, and the rector of Yattendon, Henry Charles Beeching (1859-1919) (later to become Dean of Norwich) he produced the Yattendon Hymnal (1895-99) which was "influential in the contemporary reform of hymnody and the revival of sixteenth and seventeenth century music". ${ }^{6}$ Beeching was described as a "poet and critic of reputation" and he was the husband of a niece of Bridges. ${ }^{3}$ He also wrote several other poems during these years.

Bridges did not marry until 3 September 1884 (that is, after his medical career was at an end, see below); his wife was Monica-elder daughter of his neighbour, the celebrated architect Alfred Waterhouse RA (1830-1905)-by whom he had one son (Edward [later 1st Baron Bridges]; 1892-1969) and two daughters. ${ }^{78}$ On his 80th birthday, a group of friends and admirers gave him a clavichord ${ }^{4}$ - made by $\mathrm{Mr}$ Arnold Dolmetsch (1858-1940), and engraved by Sir Emery Walker (1851-1933); a photograph of this event (reproduced in the British Medical Journal ${ }^{4}$ ) was taken by Lady Ottoline Morrell (1873-1938). Bridges died on 21 April $1930^{248}$ at his home Chilswell House, Boar's Hill, Oxford, some three miles from the city (to which he had moved in $1907^{6}$ ).

\section{ST BARTHOLOMEW'S HOSPITAL}

While at Oxford, Bridges' younger brother Edward died (in 1866); this event (and possibly Dolben's death also) possibly underlay his resolve to practise medicine. ${ }^{36}$ An outline of his medical training (1869-74) has been provided by Phillips, who has stressed the fact that at that time medical education was in the process of moving from the "Christian gentleman [image] with a broad training in the humanities", to the modern scientific discipline. Also the "controversy between Biblical and scientific explanation of creation" was, in the light of Darwin's Origin (1859), at its height. At the same time, antiseptic (Listerian) practice was being introduced into surgery.

In November 1869 (however, he probably did not begin his medical studies until $\left.1871^{5-7}\right)$, Bridges entered St Bartholomew's Hospital (figs 2 and 3) as a medical student; his intention was apparently to practise medicine until he was $40 !^{3}$ He failed

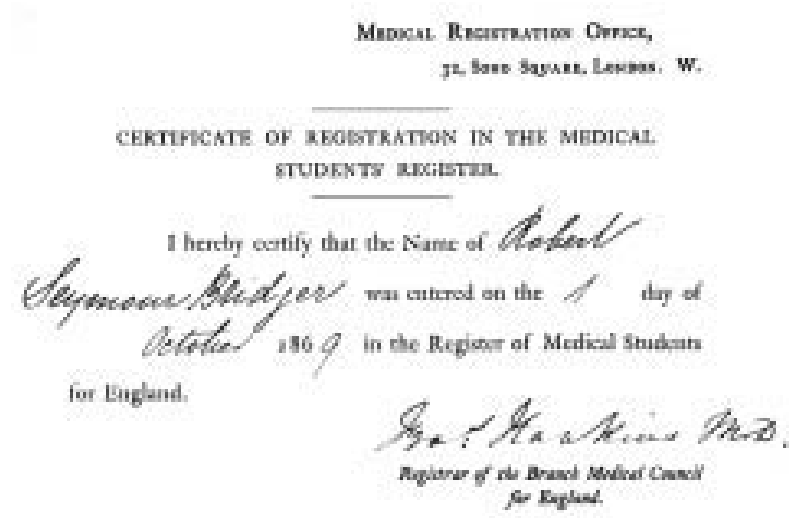

Figure 3 Bridges entry as a medical student at the Medical Registration Office, on 1 October 1869. (Reproduced with permission-museum and archives, St Bartholomew's Hospital.)

the written papers in December $1873,{ }^{9}$ but graduated BM on 17 December $1874 .{ }^{9}$ While a house physician, he made the acquaintance of Samuel Gee FRCP (1839-1911) later to become a physician at Great Ormond Street (where in 1888 he wrote an important paper "On the Coliac Affection" - gluteninduced enteropathy) and physician to George, Prince of Wales in 1901; Bridges in fact acted as his "best man"! His first "chief" (to whom he was house physician 1875-76 $6{ }^{89}$ ) was Dr Patrick Black FRCP (1813-79), senior physician at Bart's. A physician of the "old school", he was apparently admired by Bridges. ${ }^{9}$ In 1876, he passed the MRCP (by examination). On 8 June, however, he resigned as house physician to Black, and in December sent him a (humorous, Latin) farewell poem Carmen Elegiacum. . . (see below). Bridges then served as casualty physician for the years 1877-79 and vividly recorded his experience(s) (see below).

The St Bartholomew's Journal records the following (at a meeting of the St Bartholomew's House-Committee held on Tuesday 9 March 1875$)^{10}$ : "The following gentlemen were appointed House Physicians for the year commencing $1^{\text {st }}$ April next, viz: Mr Robert Bridges M.B.Oxon., M.R.C.S. [sic] upon the recommendation of Dr Black ...". Some two years later (on Tuesday 17 July 1877) the same committee ${ }^{11}:$ " . . . proceeded to the election of two Casualty Physicians ... it was Resolved That Dr Bridges [M.B. Oxon., MRCP] [together with Dr Champneys] be appointed Casualty Physicians. And their charge was read to them". On 14 November 1878, the HouseCommittee $^{12}$ was "summoned to receive the applications and testimonials of Candidates for the office of Assistant Physician the same were submitted from the following, viz: Robert Bridges, M.B. Oxon., M.R.C.P. . . Resolved that Dr Bridges [together with Dr Legg, Dr Moore, Dr Ormerod and Dr West] be admitted Candidates for the vacant office of Assistant Physician". But, at a General Court held on 27 November $1878^{13}$ : "... the Treasurer reported that ... four of the gentlemen admitted candidates by the House-Committee had since retired from their candidature ... the Court by a shew of hands unanimously elected [John Wickham Legg (1843-1921) ${ }^{14}$ M.D. Lond. F.R.C.P] to be the Junior Assistant Physician to this Hospital. The Treasurer thereupon declared the said Dr Legg duly elected ...". In 1878 Bridges became assistant physician (and later a full physician) to the Hospital for Sick Children, Great Ormond Street.

Bridges began his term as physician to the St Bart's Hospital Casualty Ward in late 1876. A statistical précis of his experience(s) in these years is recorded in an Account of the Casualty Department. ${ }^{56915} \mathrm{He}$ was in effect the "joint 'filtrator' of outpatients from 9 o'clock to 12 noon". $^{4}$ Out of $>151000$ patients "relieved" at the hospital in 1877-78, he personally saw 30940 (more than two thirds were new cases ${ }^{4}$ ) of them 
(that is, 148 daily, an average of 1.28 min per case), and ordered $>200000$ doses of medicine containing iron. ${ }^{56}$ An anonymous writer in the British Medical Journal considered, in the light of this article, that he held "strong views decidedly unfavourable to indiscriminate out-patients and casualty relief, most of which he felt would be more properly and more efficiently given by general practitioners than by hospital physicians . ...". In summary, Bridges considered that it was totally impossible to combine the diagnosis of this large number of patients, with efficiency. The prevailing system was in fact virtually inoperable! People were also ignoring good country doctors (GPs) and, instead, making pilgrimages to St Bartholomew's. ${ }^{9}$ A further criticism was directed to extraneous noise, which precluded adequate auscultatory diagnosis:

"the rattle of carts in the street, the hum of voices inside, the slamming of doors, the noise of people walking about, the coughings of all kinds, the crying of babies, the scraping of impatient feet, the stamping of cold ones, the chinking of the bottles and zinc tickets, and, after eleven o'clock, the hammering, sawing, and tinkering of the carpenters and blacksmiths who came not unfrequently at that hour to set things generally to rights".

His outspoken condemnation of the system would probably have precluded a further appointment at Bart's even if he had applied"! (Even today the medical hierarchy ["establishment"] hates criticism and suggestions for improvement.)

Before writing the "casualty paper", Bridges had contributed an article (also to the St Bartholomew's Hospital Reports) on a case of rheumatic fever which was treated with splints (in 1876). This was his first medical paper-a single case report of a patient suffering from severe rheumatic fever and extreme joint pain. ${ }^{16}$ It is well written and displays his already accomplished literary style:

"This method of treatment [that is, 'masterly inactivity', together with morphine, before salicylates were known to be effective], if treatment it may be called, has found support in the tendency of a therapeutic fashion, that by the watchword of expectancy has not only taught prudence, but has often excused indolence and spared judgement; so that it is not a matter of wonder to the student to see some patients waiting for their pain to pass off as others do for their fever, while the knowledge that inflammation of the heart is more serious than that of the knee is sufficient erudition to divert their attention and defer their efforts. Such considerations, coupled with the common agreement of surgeons concerning the treatment of inflamed joints, led me to ask leave to publish [an] account of a case of rheumatic fever of unusual severity treated by splints. . . . since during five years at our Hospital I had never seen [the method] put in practice, nor even heard it mentioned, so it was not till I became responsible for the treatment of a patient who seemed to be dying of sheer pain, that being myself compelled to seek some such resource, I had an opportunity of witnessing its effects".

Thus although at Bart's for seven years, he had contributed only three medical publications. ${ }^{5}$

\section{GREAT NORTHERN HOSPITAL (1876-85)}

From St Bartholomew's, Bridges went to the Great (later Royal) Northern Hospital, then situated in Caledonian Road (fig 4). ${ }^{17}$ This hospital had been founded in York Road, Kings Cross by Sherard Freeman Statham (1826-58) in 1856; funding for this unendowed charity, which did not require an attendance fee, or a "letter of recommendation" was an ongoing problem; figs 5 and 6 show posters for appeals for funding for the hospital. During Bridges' time several went out for this ailing charity. ${ }^{18-22}$ The aim of the hospital was to care for the sick poor, amounting to half a million inhabitants in a large district (which included factories and several railway termini) of London, north of Pentonville and Euston Roads; shortly after Bridges' resignation (see below) it was amalgamated with the Central Hospital for North London ${ }^{22}$ to become the Great Northern Central Hospital.

Bridges' successful application for the position of physician to the outpatient department at the Great Northern Hospital was minuted at a Medical Committee meeting held at 5 Henrietta Street on 13 April $1876^{23}$ :

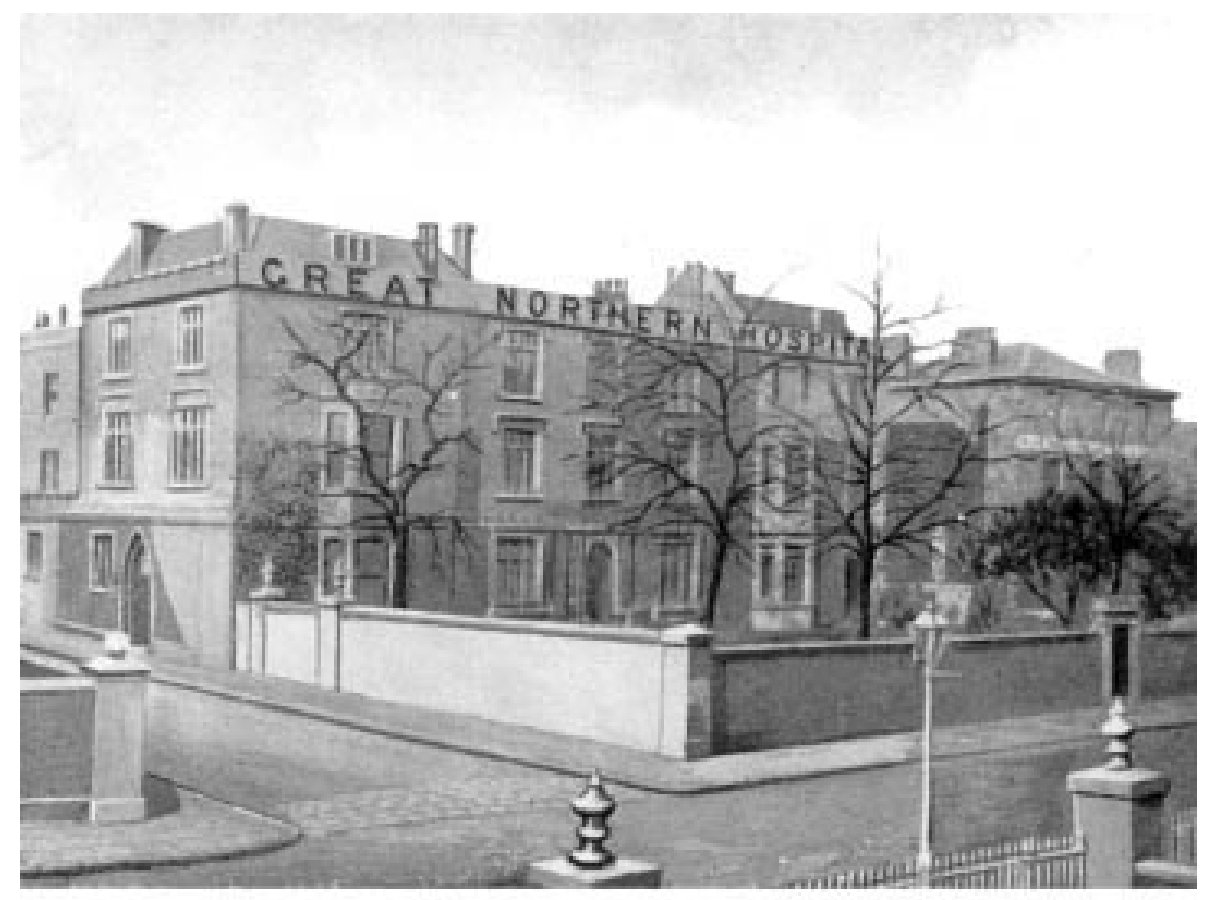

The Caledonian Road Site. occupied by the Hospital from 1864 to 1888

Figure 4 The Great Northern Hospital when situated in the Caledonian Road (1864-88). ${ }^{17}$ 
GREAT NORTHERN HOSPITAL, KING'S CROSS.

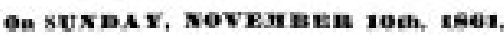

TWO SER MONS

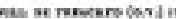

CHRIST CHURCH, STREATHAM,

nec is ses Mones:

By the REV. T. J. ROW SELL, M.A.,

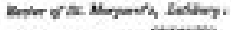

By the REV. W. LEES BELI, M.A.,

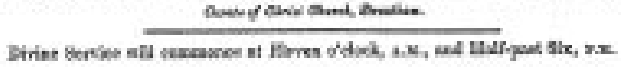

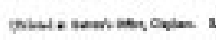

Figure 5 Notice of two charity sermons in 1861 when the Great Northern Hospital was situated at King's Cross, that is before its removal to the Caledonian Road in 1864. (Reproduced with permission, the London Metropolitan Archives.)

"A letter was read from the Secretary of the Executive requesting the Medical Committee to examine and report upon, the applications of $\mathrm{D}^{\mathrm{r}} \mathrm{W}$. Squire, and $\mathrm{D}^{\mathrm{r}}$ Bridges for the vacant office of Physician to the out-patients department, and after due consideration it was proposed, seconded, and carried 'that the Medical Committee having examined the applications, with testimonials, for the vacant office of Physician to the out-patients department, recommend $\mathrm{D}^{\mathrm{r}}$ Bridges for the appointment"'. This appointment was ratified at a meeting of the House Visitors (held in the Hospital's Board Room) on 26 April, ${ }^{24}$ and at one of the Executive Committee held on 5 May $1876^{25}$ : "The appointment of Dr R Bridges by House Visitors on 26 April confirmed". At his first attendance at a meeting of the Medical Committee held at 91 Harley Street, Cavendish Square on 11 May, the Chairman (Mr Thomas Carr Jackson FRCS, 1823-78) duly welcomed him "in a few appropriate words to which $\mathrm{D}^{\mathrm{r}}$ Bridges replied". Incidentally on some occasions, his name is misspelt (in the minute books) as Brydges.

Shortly after his arrival at the Great Northern Hospital, Bridges is credited with the prevention of a serious smallpox

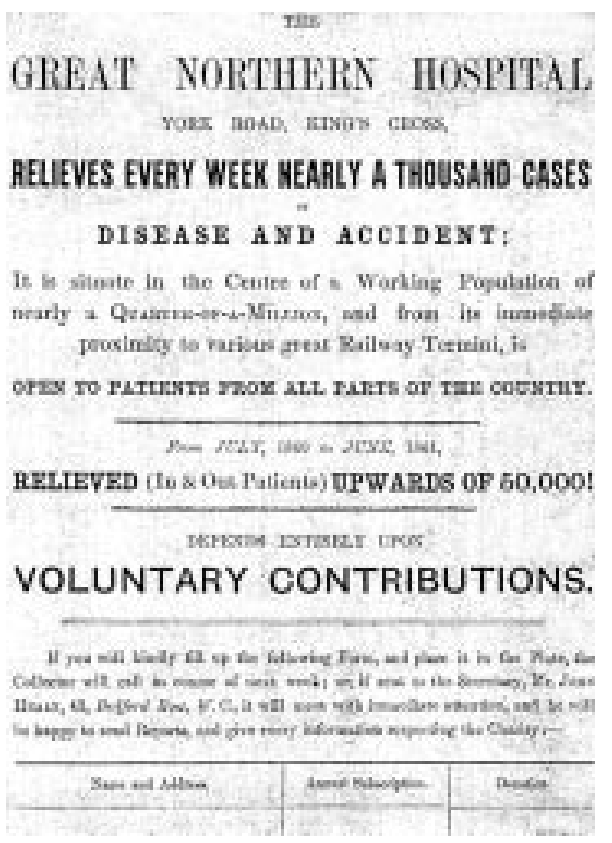

Figure 6 Advertisement for voluntary contributions, in 1861, before the removal to the Caledonian Road site in 1864 .

(Reproduced with permission, the London Metropolitan Archives.) outbreak there (in September 1876), a by no means uncommon problem during that decade. ${ }^{9}$ His strategy was as follows: he immediately moved all patients who were sick enough to be hospitalised to Homerton Hospital; the remainder were vaccinated, bathed, provided with clean clothing, and sent home. ${ }^{17}$ All of the staff were vaccinated, all bedding disinfected and washed, the wards fumigated with sulphur, and every surface washed down with carbolic acid. ${ }^{9}$ The House Visitors and Executive Committee expressed their great satisfaction that the emergency had been so excellently handled. In 1879, Bridges was made a full physician to the Great Northern Hospital. ${ }^{9}$

At a meeting of the Medical Committee held on 14 July $1881,{ }^{26}$ "Dr Bridges [who was absent] was reported ill". News of Bridges resignation, however, did not come until a meeting of the Medical Committee held at 5 Henrietta Street W, on 30 June $1885^{27}$ :

"A letter from the Secretary to the Hospital was then read, announcing the resignation of Dr Robert Bridges [this had already been reported to a meeting of the Committee of Management held on 2 June ${ }^{28}$ : 'A letter was read from $\mathrm{D}^{\mathrm{r}}$ Robert Bridges tendering his resignation as Physician to the Hospital which was accepted with regret . . .'] and enclosing applications with testimonials from two candidates for the office of Physician, thus rendered vacant ... Dr. C. E. Beevor FRCP [1854-1908] of 33 Harley Street, W was recommended to the Committee of Management"'.

Bridges thus retired from medicine in 1885 and "gave himself up wholly to literature". ${ }^{4}$ His medical career was therefore to end (at the age of 37 years) sooner than he had planned ${ }^{3}$; in June 1881 he had suffered from a severe attack of pneumonia $^{2}$ (complicated by empyema ${ }^{6}$ ), and in November look of absence from the Great Northern Hospital in order to tour Italy and Sicily (with a view to recovering his strength).

In 1890, Bridges was nominated for the FRCP; he declined this honour (fig 7) for reasons which remain unclear. However, he was elected in $1900 !^{4}$

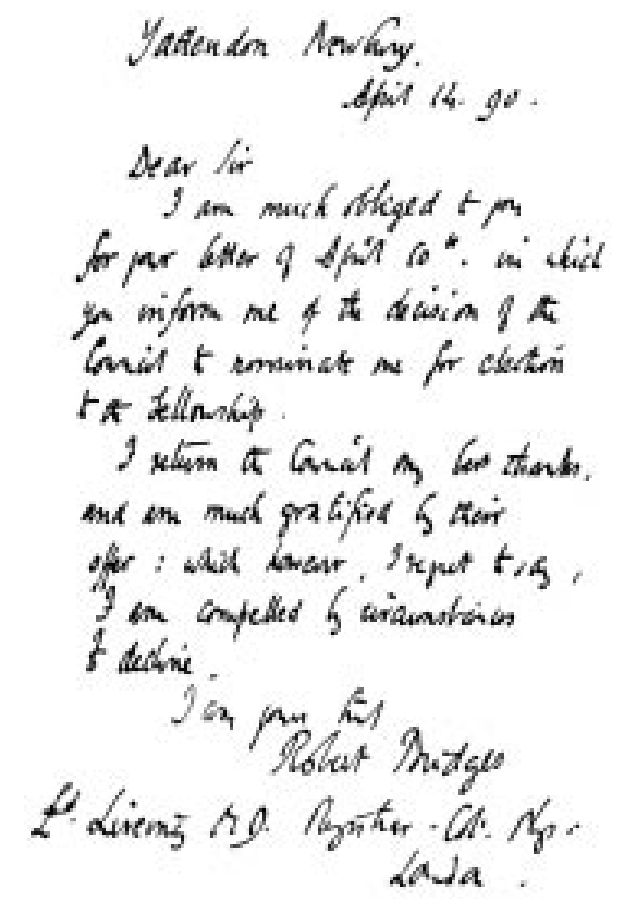

Figure 7 Letter written by Bridges to the Registrar (Edward Liveing, 1832-1919) of the (Royal) College of Physicians declining the nomination by Council for election to the FRCP. (Reproduced with permission, Harveian Librarian, Royal College of Physicians of London.) He was subsequently elected FRCP in 1900. 
The sole example of a poem written completely from Bridges medical experience is On a Dead Child':

"Perfect little body, without fault or stain on thee, With promise of strength and manhood full and fair! Though cold and stark and bare,

The bloom and the charm of life doth awhile remain on thee... So quiet! doth the change content thee?-Death, whither hath he taken thee?

To a world, do I think, that rights the disaster of this? The vision of which I miss,

Who weep for the body, and wish but to warm thee and awaken thee?

Ah! Little at best can all our hopes avail us

To lift this sorrow, or cheer us, when in the dark,

Unwilling, alone we embark,

And the things we have seen and have known and have heard of, fail us".

\section{LIFE AFTER MEDICINE}

After marriage, Bridges settled down in Yattendon in the Berkshire Downs, ${ }^{3}$ within easy reach of Oxford. He lived in a “. . . pleasant old red-brick house with [a] rook-haunted garden" which had "just the combination of beauty, simplicity and remoteness suitable to a poet of his Miltonic order". ${ }^{23}$ Here, he was to spend the first 20 years of his married life. While there (with Wooldridge and Beeching) he compiled the Yattendon Hymnal. ${ }^{2}$ In 1895, Bridges was invited (by a strong list of supporters) to stand for election to the Chair of Poetry at Oxford; this he declined to do!

In 1904, his wife suffered from ill health, and they both spent nine months in Switzerland; following this, they did not return to Yattendon, but settled at Boar's Hill, near Oxford. ${ }^{2} \mathrm{He}$ subsequently built Chilswell House.

Bridges poetical reputation was made by his "Shorter Poems" which were published in 1873, 1879, and 1880; these books contain frequent references to "the sea, sky, cliffs, birds and flowers of the south coast", ${ }^{6}$ that is, where he spent his early years. For details of his subsequent poetical works, see Newbolt. ${ }^{2}$ His theory of "stressed verse" was derived in part from his friend (Father) Gerard Manley Hopkins. ${ }^{2}$ This was apparently not to everyone's taste and partly gave rise to "the legend of Our Dumb Laureate", ${ }^{29}$ largely because his output of "official" poems was exceedingly limited.

Bridges' artistic and musical bent had long inclined him to an interest in English pronunciation and spelling, as well as prosody. ${ }^{6}$ An anonymous writer in the British Medical Journal recorded that "nearly half a century [after his active medical career was at an end] his pen turned again for a moment to a subject related to medical science ... in a tract on the language of anatomy - a brilliant attempt to bring order out of the terminological chaos into which British anatomy had been plunged". ${ }^{4}$ His objective was to "condemn the action of those [who were] moving to introduce a formal Latin international terminology into the British schools of anatomy, on the false notion that it will be of service to international science" ${ }^{4}$ During his medical career, he wrote a Latin elegiac poem of 556 lines, ${ }^{5}$ in which he celebrated the history of the foundation of St Bartholomew's Hospital, and lightly treated of the members of the staff'. ${ }^{4}$ This poem (Carmen elegiacum de Nosocomio Sti. Bartolomaei..., which was dedicated to Black; see above) ends with a description of the author's examination for the MRCP. ${ }^{5}$

In March 1924 he and his wife visited the USA, where they stayed at Ann Arbor for three months as guests of the University of Michigan. ${ }^{6}$ Five years later, he received the Order of Merit. ${ }^{36}$ He was also given the following academic honours: Hon Fellow of Corpus Christi College, Hon D Litt (Oxon), and Hon Ll D of St Andrews, Harvard, and Michigan. ${ }^{26}$

\section{THE POET LAUREATESHIP}

Bridges succeeded Alfred Austin (1835-1913)—who had apparently reduced the office "to insignificance" —as Poet
Laureate in 1913. Rudyard Kipling (1865-1936) would apparently have been a more popular choice. ${ }^{6}$ This appointment, recommended by H H Asquith (1852-1928) (and ratified by King George V; 1865-1936) was duly announced in The Times: "The King has been pleased to approve the appointment of $\mathrm{Mr}$. Robert Bridges, D. Litt., to be Poet Laureate" ${ }^{30}$ The same newspaper carried a leading article entitled "The New Poet Laureate" ${ }^{31}$ The obituarist in the St Bartholomew's Hospital Journal considered that during the 19th century, there had been "nearly thirty medical poets" but "few of them were good poets [and] only three names ... emerge above the level of mediocrity-[Thomas Lovell] Beddoes [1803-49], [John] Keats [1795-1821] and Bridges ...". ${ }^{5}$

His first volume of verse had appeared in 1873 (see above) while he was still a medical student ("a thin volume of 125 pages" ${ }^{\prime \prime}$ ), and his last (The Testament of Beauty) - his greatest achievement as Poet Laureate ${ }^{2}$-on his 85 th birthday. The Collected Poems was published in six volumes in $1904 .^{56}$

\section{A MEDICAL CAREER AS A TRAINING GROUND FOR A POET}

It has been suggested that the profession of medicine is a good training ground for the aspiring poet. ${ }^{32}$ The author of this article quotes Sir Walter Langdon-Brown FRCP (1870-1946) as being of the opinion that Bridges "would have been unable" to write The Testament of Beauty without [his medical background]. His poem On a Dead Child (see above) published while he was actively employed at Great Ormond Street, expressed both passion, and a "sense of grievous things". LangdonBrown wrote: "he wished his poetry to express the philosophy of life he acquired from natural science in general and from medicine in particular" ${ }^{32}$ Sickness, together with death are sympathetically portrayed in Winter Nightfall.

\section{EPILOGUE}

Bridges' medical career lasted only 10 years, but during this period he had absorbed "the impressions of life and humanity". ${ }^{5}$ This "ultimately found expression in . . . his last and greatest poem, The Testament of Beauty". He was certainly not averse to criticising the medical establishment. Bridges saw through a lot of the "humbug that existed in Victorian medicine [and this is] amply shown in the 'casualty' account [see above]". ${ }^{32}$ In fact, his comments in this account, the criticism being based on the ground of impractibility, has a close parallel in the widespread criticism of general practice today, that is, the fact that the pace of work is too great to allow every patient the degree of attention which his/her case justifies!

The Times in announcing Bridges' death "with much regret", ${ }^{33}$ carried a leading article entitled "The Poet Laureate"; this praised The Testament of Beauty (which he had published at the age of 85 years). ${ }^{34}$ This tribute was followed by several notices of appreciation. ${ }^{35-40}$ Only two of these, however, acknowledged the fact that he was a member of the medical profession. ${ }^{35}{ }^{38}$ Paget Toynbee commented on some words Bridges had written in $1920^{35}$ :

"The 'distinction' that I set most store by is my Fellowship of the Royal College of Physicians, which dates 1900. I am also Hon. Fellow of the Royal Society of Medicine".

And Sir John Rose Bradford Bt PRCP (1863-1935) conveyed a "vote of condolence to the family of the late Poet Laureate" at a meeting of the Royal College of Physicians held on 24 April 1930. ${ }^{38}$

As an individual "Bridges [apparently] possessed a magnificent physique, and in his later years was as handsome an old man as anyone could wish to see". ${ }^{.5}$ This writer in the St Bartholomew's Hospital Journal continued: "With his shock of white hair, piercing eyes, picturesque clothing and abrupt manners, he may have appeared to the casual visitor to have been 'playing-up' to the rôle of Laureate, but this was not the case". 
In conclusion, an anonymous contributor to the British Medical Journal wrote": "The medical profession may well feel proud that its only Poet Laureate ... was a great poet and a fine scholar, and that the years he spent in medicine were a vital contribution to [his] training for the life of letters".

\section{ACKNOWLEDGEMENT}

Based on a paper delivered to the Historical Resources Panel, The Royal College of Physicians of London on 5 December 2001.

\section{REFERENCES AND NOTES}

1 Laurie H. Verses of the poets laureate from John Dryden to Andrew Motion. London: Orion, 1999: 132-43.

2 [Newbolt H.] Mr. Robert Bridges, O.M. Times, London 1930; 22 April: 17.

3 Thompson E. Robert Bridges 1844-1930. Oxford: Oxford University Press, 1944: 131

4 Anonymous. Robert Bridges. BM 1930;i :788; Obituary. Robert Bridges, O.M., D.Litt., LI.D., M.B., F.R.C.P. BM 1930; i : 801.

5 Obituaries. Robert Bridges, O.M.: Poet Laureate. 21 April 1930. St Bartholomew's Hospital Journal 1930:37:138-41.

6 Smith NC. Bridges, Robert Seymour (1844-1930). In: Weaver JRH, ed. Dictionary of national biography 1922-1930. London: Oxford University Press, 1937: 115-19.

7 Anonymous. Bridges, Robert, O.M. Who Was Who, 1929-1940. Vol 3. London: Adam and Charles Black, 1947: 160-1.

8 Anonymous. Bridges, Robert Seymour, O.M. In: Brown GH, ed. Lives of the fellows of the Royal College of Physicians of London 1826-1925. London: Royal College of Physicians, 1955: 417.

9 Phillips C. Robert Bridges: a biography. Oxford: Oxford University Press, 1992: 364.

10 Minutes of the St Bartholomew's House Committee. St Bartholomew's Journal (1872-1879) [Ha 1/24] 1875, 9 March: 237.

11 Minutes of the St Bartholomew's House Committee. St Bartholomew's Journal (1872-1879) [Ha 1/24] 1877, 17 July: 416-17.

12 Minutes of the St Bartholomew's House Committee. St Bartholomew's Journal (1872-1879) [Ha 1/24] 1878, 14 November: 542

13 Minutes of the General Court. St Bartholomew's Journal (1872-1879) [Ha 1/24] 1878, 27 November: 547-8.

14 John Wickham Legg, had been elected FRCP in 1876, having been Casualty Physician to St Bartholomew's Hospital since 1870. In 1883 he delivered the Bradshaw lecture at the RCP. After two attacks of rheumatic fever in 1887, he abandoned medicine entirely, and devoted the rest of his life to the study of liturgies. His "outlook was conservative in the extreme and he attacked the proposed revision of the Prayer Book". He was accepted as the greatest living English authority on liturgiology.

15 Bridges R. An account of the casualty department. St Bartholomew's Hospital Reports 1878;14:167-82.
16 Bridges $\mathbf{R}$. A severe case of rheumatic fever treated successfully by splints. St Bartholomew's Hospital Reports 1876;12:175-81.

17 Jewesbury ECO. The Royal Northern Hospital 1856-1956: the story of a hundred years' work in north London. London: HK Lewis \& Co Ltd, 1956: 157.

18 Saulez T. The Great Northern Hospital. Times, London 1863; 8 December: 5 .

19 Lloyd RH. Times, London 1865; 27 December: 5

20 Reid G. A plea for the sick poor. Times, London 1869; 30 December: 9.

21 Reid G. Home charities. Times, London 1871; 27 September: 5

22 Anonymous. Hospital accommodation in north London. Times, London 1884; 21 January: 8

23 Great Northern Hospital. Medical Committee Minutes. Vol 219 December 1875-1 1 February 1886); 1876, 30 April: 13 [London Metropolitan Archives]

24 Great Northern Hospital. Committee of Management Minutes (4 July 1872-7 January 1886); 1876, 26 April: 230 [London Metropolitan Archives].

25 Great Northern Hospital. Committee of Management Minutes (4 July 1872-7 January 1886); 1876, 5 May: 231-2. [London Metropolitan Archives].

26 Great Northern Hospital. Medical Committee Minutes. Vol 219 December 1875-11 February 1886); 1881, 14 July: 150 [London Metropolitan Archives].

27 Great Northern Hospital. Medical Committee Minutes. Vol 219 December 1875-1 1 February 1886); 1885, 30 June: 302-6 [London Metropolitan Archives]

28 Great Northern Hospital. Committee of Management Minutes (4 July 1872-7 January 1886); 1885, 2 June: 567-70 [London Metropolitan Archives].

29 Shafar J, Price PA. Doctor \& Dumb Laureate. The Bart's Journal 1981 autumn: 9-15.

30 Anonymous. New Poet Laureate. Appointment of Mr Robert Bridges. Times, London 1913; 17 July: 6

31 Anonymous. Leading article. The New Poet Laureate. Times, London 1913; 17 July: 7

32 Potter J. Robert Bridges (1844-1930): medicine as a training for poetry? Oxford Medical School Gazette 1953; 5 (no 2): 74-84; St Bartholomew's Hospital Journal 1954;53(no 3): 62-8.

33 Anonymous. Death of Mr Robert Bridges, O.M. Times, London 1930; 22 April: 12

34 Anonymous. Leading article. The Poet Laureate. Times, London 1930; 22 April: 13

35 Toynbee $\mathbf{P}$. The Poet Laureate. Times, London 1930; 23 April: 13.

36 Magnus L. The Poet Laureate. Times, London 1930; 23 April: 13.

37 Mansbridge A. Mr Robert Bridges, O.M. Times, London 1930; 24 April: 14

38 Anonymous. Royal College of Physicians. Election of Fellows. Times, London 1930; 25 April: 7.

39 Denniston JG. The Poet Laureate. Times, London 1930; 28 April: 10.

40 Parker SE. The Poet Laureate. Times, London 1930; 3 May: 8. 